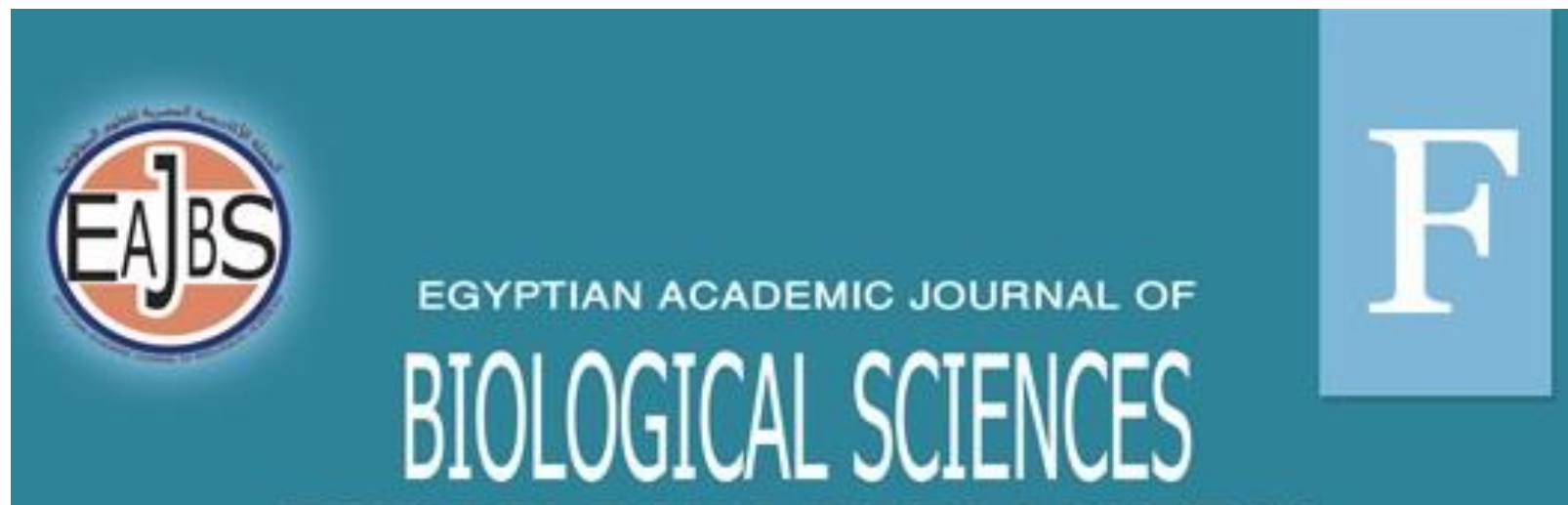

TOXICOLOGY \& PEST CONTROL

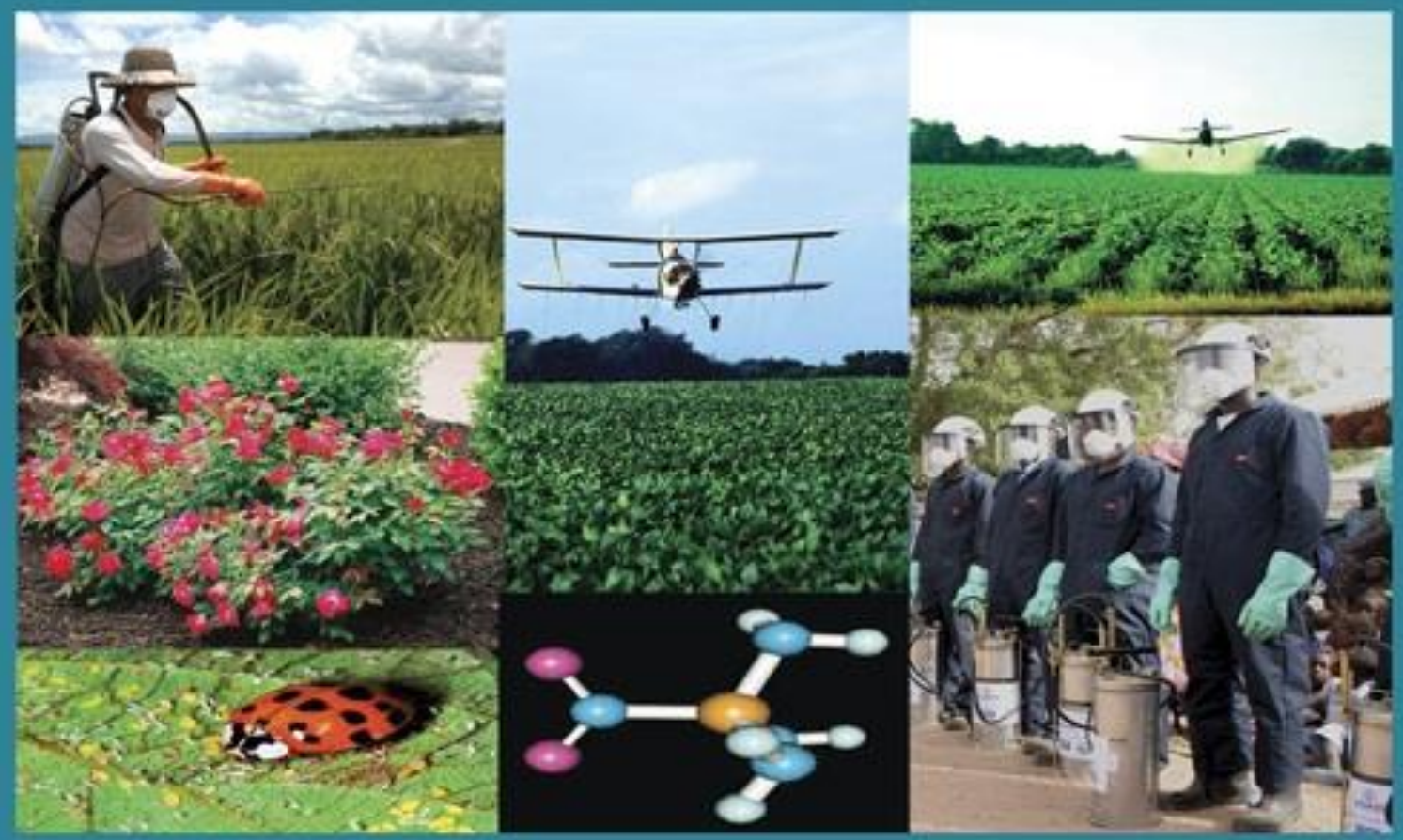

ISSN

2090-0791

WWW.EAJBS.EG.NET

Vol. 13 No. 1 (2021)

$\underline{\text { www.eajbs.eg.net }}$

$\overline{\text { Citation :Egypt. Acad. J. Biolog. Sci. (F.Toxicology \& Pest control) Vol.13(1)pp177-187(2021) }}$

DOI: 10.21608/EAJBSF.2021.153757 
Egypt. Acad. J. Biolog. Sci., 13(1):177- 187 (2021)

Egyptian Academic Journal of Biological Sciences

F. Toxicology \& Pest Control

ISSN: 2090 - 0791

http://eajbsf.journals.ekb.eg/

\title{
Biological Control of Myzus Persicae (Sulzer) By Release Coccinella Septempunctata L. On Strawberry Plants Under Glasshouse Conditions
}

\author{
Amna, M. H. Maklad; Seham, M. Elmahdy ; Afia, Y. E. ; Heba, A. Alghnam and \\ Wedyan, F. M. Hassan \\ Plant Protection Research Institute, A.R.C., Dokki, Giza, Egypt \\ *E-Mail : Dr.amnamaklad@yahoo.com
}

\section{ARTICLEINFO}

Article History

Received: $2 / 12 / 2020$

Accepted: 5/3/2021

\section{Keywords:}

Biological Control, Myzus Persicae, Coccinella

Septempunctata, Strawberry Plants,

Glasshouse

Conditions
This study was carried out to evaluate the management of Myzus persicae (Sulzer) (Hemiptera: Aphididae) which infesting strawberry plants Fragaria ananassa (L.) by releasing different levels of the seven spotted lady beetle, Coccinella septempunctata L. (Coleoptera: Coccinellidae). This study was carried out under glasshouse conditions at two locations (Governorates), Nobariya (Behera governorate) and Perkash (Giza governorate) during season 2019/2020.

The seven spotted lady beetle, C. septempunctata was released for one time at the beginning of February on strawberry plants at the two locations at rates of 30, 60 and 90 eggs/plant. In the first level of release (30 eggs/plant), at Behera Governorate the reduction percentages in the population of $M$. persicae increased gradually whereas it was 21.0, 31.0, 41.0, 44.0 and 50.0\% in mid-February, first-March, mid-March, first-April and mid-April, respectively. The same trend was achieved at Giza Governorate. Also, in the second level of release (60 eggs/plant), at Behera Governorate the reduction percentages in the population of $M$. persicae increased gradually whereas it was 27.0, 33.0, 44.0, 48.0 and 55.0\% in midFebruary, first-March, mid-March, first-April and mid-April, respectively. The same trend was achieved at Giza Governorate. Lastly, at the third level of release (90 eggs/plant), at Behera Governorate the reduction percentages in the population of $M$. persicae increased gradually whereas it was 29.0, 37.0, 41.0, 49.0 and 52.0\% in mid-February, first-March, mid-March, firstApril and mid-April, respectively. In addition, the same trend was achieved at Giza Governorate.

\section{INTRODUCTION}

Strawberry plants Fragaria ananassa (L.) consider one of the most important vegetable plants in Egypt and all over the world which is cultivated in the open field and under glasshouse conditions. Also, its cultivated area increased gradually during the last years, especially in the newly reclaimed areas for purposes of local consumption and exportation to the foreign markets. Francisco, et al. (2011)

Egypt considers one of the largest producers and exporters of strawberry (seedlings and fruits) all over the world where it ranks fifth in the world in the production and export 
of strawberry (seedlings and fruits), The area of the plantation with strawberry seedlings both fresh seedlings and freezing seedlings in Egypt is about 21573 fed. It is divided into about 16459 fed (fresh planting) and about 5113 fed (cooled planting). Food and Agriculture Organization (F.A.O), 2017

Strawberry plants infested by a large scale of insects belong to many orders and families. Green Peach Aphid, Myzus persicae (Sulzer) (Hemiptera: Aphididae) has one of the most important insects that infesting strawberry seedlings. $M$. persicae recently become a major insect pest of strawberries in Southern California and causes numerous damage in both quantity and quality for the crop directly by plant juice to loosen or indirectly by plant disease-transmitting John, et al. (2005). Also, Jian and Nick (2009) in California found that the Green Peach Aphid, M. persicae has emerged as a major insect pest of many horticultural crops such as strawberry in California.

The seven spotted lady beetle, Coccinella septempunctata L. (Coleoptera: Coccinellidae) is the commonest lady beetle known in Egypt, it is an important predator of many aphid species; eggs and small nymphs of mealybugs, jassids, eggs, and larvae of cotton leafworm (Ibrahim 1948 \& 1955 and Bilashini et al., 2017). The adults and small stages are often encountered in large numbers on the plants infested with aphids. They feed on these harmful insects and often play a great role in suppressing them under control. Both the adult and larval stages feed on insects harmful to plants, such as aphids and scale insects (Anonymous, 1997). Adults can be killing up to 100 aphids per day (Arnett, et al., 1980). The seven spotted lady beetle, C. septempunctata lives in a wide variety of habitats, any place where there are plants and aphids may attract these species (Fleming 2000). The lady beetle kills its prey outright and then devours it (Waldbauer 1998). Under field conditions, numerous coccinellids consume nectar, honeydew, pollen, fruit, vegetation, and fungus. These non-prey foods are used by coccinellids to increase survival when prey is scarce, reduce mortality during diapause, fuel migration, and enhance reproductive capacity. Each of these non-prey foods has unique nutritional and defensive characteristics that influence its suitability for lady beetles (Lundgren 2015).

This study was carried out to evaluate the management of the green peach aphid $M$. persicae which infesting strawberry plants by releasing different levels of the seven spotted lady beetle, C. septempuncta and this study was carried out at two locations (Governorates), Nobariya (Behera governorate) and Perkash (Giza governorate) during season 2019/2020.

\section{MATERIALS AND METHODS}

Mass Rearing Of The Seven Spotted Lady Beetle, Coccinella septempunctata L. and Its Prey The Cowpea Aphid, Aphis craccivora (Koch):

\section{Mass Rearing of A. craccivora As A Prey:}

Aphis craccivora is considered the most preferable prey for the mass production of

C. septempunctata. A strong culture of this aphid should be available during the rearing time to maintain the predator rearing process.

The broad bean, Vicia faba seeds were planted in plastic trays $(25 \mathrm{X} 40 \mathrm{X} 15 \mathrm{~cm})$ or foam trays $(60 \mathrm{X} 25 \mathrm{X} 20 \mathrm{~cm}$ with 109 wholes) that contained peat muss. The seeds were planted at 1-2 cm deep and followed with irrigation and fertilizers as required. When the first leaflet appeared after about one week from cultivation. Bean leaves were infested with $A$. craccivora which distributed over the new foliage of cultivated trays. Culturing of faba bean plants and artificial aphid infestation was a continuous process carried out at weekly intervals.

The infested trays were followed until the population of $A$. craccivora increased and become suitable for use as prey to the lady beetle, $C$. septempunctata. A. craccivora colonies 
were cultured under laboratory conditions $\left(23 \pm 2^{\circ} \mathrm{C}\right.$ and $60 \pm 5 \%$ R.H.) on broad beans (Vicia $f a b a$ ). Such leaves of beans were infested by different stages of aphids and kept under a glass chimney which its upper opening was covered with white muslin. The potted plants were irrigated and fertilized whenever necessary and kept in wooden cages $(100 X 135 \mathrm{X} 135 \mathrm{~cm})$ with nylon gauze sides using the method described by (Mangoud 2003 and Mahyoub et al., 2013). A. craccivora and C. septempunctata instars were originally collected from an agricultural field.

\section{Mass Rearing of $C$. septempunctata:}

When the population of $A$. craccivora increased and reached suitable density individuals (approximately 100 individuals/plant,) on faba bean plants these plants were inoculated with $C$. septempunctata. The stock culture of the ladybird was obtained from infested plants and transferred to the laboratory. Only 10 adults $\hat{\sigma}+10$ adults $q$ of ladybird (to prevent larval cannibalism) were transferred to rearing cages $(30 \mathrm{~cm}$ diameter X $25 \mathrm{~cm}$ high) and kept in wooden cages $(100 \times 135 \times 135 \mathrm{~cm})$ with nylon gauze sides. To maintain the predator culture, a suitable number of the prey was daily offered to the predator (Mahyoub et al., 2013).

\section{Egg Picking:}

The method for egg-laying [black polyethylene strips fixed inside a plastic cylindrical ( $10 \mathrm{~cm}$ length $\mathrm{X} 2 \mathrm{~cm}$ diameter) for laying eggs and put in the rearing pots]. After laid egg-masses, they were removed from plastic cylinders to separate the egg-masses from the cylindrical plastic and to be ready to stick on the carton paper card for release. The plastic cylinder was checked twice/day for egg-masses because of the cannibalistic habits of the adults, especially when there was a shortage of host food. In order to provide the developing larva with sufficient food throughout their developmental period, it was necessary to increase the amount of food with the advancement of their development (Mahyoub et al., 2013).

\section{Release of $C$. septempunctata:}

Releasing study was conducted on strawberry plants which are grown in two locations (governorates), Nobariya (Behera governorate) and Perkash (Giza governorate) during season 2019/2020 under glasshouse conditions.

The selected plants for the present investigation were away from any pesticide contamination. Both in the two places, the glasshouse divided into three plots $(3 \times 5 \mathrm{~m}$ for each) for strawberry (fresh seedlings) which were cultivated in September month 2019. Each plot for each release level and each plot also divided into three replicates for that release level and another three replicates as control. The normal release and recommended agricultural practices were applied, also no chemical control against aphid was used during the whole experimental period.

Naturally, the numbers of $C$. septempunctata stages were recorded. Therefore, three levels of $C$. septempunctata eggs; the first level consists of 30 eggs (one card), the second level consists of 60 eggs (two cards) and the third one consists of 90 eggs (three cards) were released to encouragement the normal predator population to reduce the aphid. $C$. septempunctata were released (one time) by the beginning of February on strawberry plants at the two places in the 2020 season.

Samples were randomly taken bi-weekly at the two places and counting started from the beginning of February in strawberry plants. Twenty new plants were examined from each plot (five leaves for each plant), were made by a hand lens for counting the alive insects and the predator and took the mean numbers. Both surfaces of the leaf were inspected for the presence of aphid (Mangoud 2000). 


\section{Statistical Analysis:}

The percent reduction of The Green Peach aphid $M$. persicae after $C$. septempunctata was released was calculated according to Henderson and Tilton equation (1955).

The data were subjected to analysis of variance (ANOVA) and the means were compared by L.S.D. test at 0.05 level, using SAS program (SAS Institute, 1988).

\section{RESULTS AND DISCUSSION}

This study was carried out to evaluate the management of Myzus persicae (Sulzer) (Hemiptera: Aphididae) which infesting strawberry plants by releasing three levels $(30,60$ and 90 eggs) of the seven spotted lady beetle, Coccinella septempunctata L. (Coleoptera: Coccinellidae). This study was carried out under glasshouse conditions at two locations (Governorates), Nobariya (Behera governorate) and Perkash (Giza governorate) during season 2019/2020.

\section{Nobariya (Behera Governorate):}

Three levels of $C$. septempunctata eggs; the first level (30 eggs on one card), the second level (60 eggs on two cards) and the third level (90 eggs on three cards) were released (one time) by the beginning of February 2020 on strawberry plants.

\section{First Level of Release (30 eggs/plant):}

Results in Table (1) and Figure (1) indicated that the number of $M$. persicae in the $1^{\text {st }}$ release plot decreased gradually from 35 on the $1^{\text {st }}$ February to $30,23,15,10$ and 6 individuals/plant, in mid-February, first-March, mid-March, first-April and mid-April, respectively as compared to control which aphid populations changed from 37 individuals/plant on first-February to 40, 44, 50, 59 and 70 individuals/plant in the same dates, respectively. The present results showed that the percent reduction of $M$. persicae in the $1^{\text {st }}$ release plot increased gradually to reach $21.0,31.0,41.0,44.0$ and $50.0 \%$ in midFebruary, first-March, mid-March, first-April and mid-April, respectively.

\section{The Second Level of Release (60 eggs/plant):}

Results in Table (2) and Figure (2) indicated that the number of $M$. persicae in the $2^{\text {nd }}$ release plot decreased gradually from 33 on the $1^{\text {st }}$ February to $27,21,14,9$ and 5 individuals/plant on mid-February, first-March, mid-March, first-April and mid-April, respectively as compared to control which aphid populations changed from 35 individuals/plant on first-February to $39,45,53,65$ and 79 individuals/plant in the same dates, respectively. The obtained results showed that the percent reduction of $M$. persicae in $2^{\text {nd }}$ release plot increased gradually to reach $27.0,33.0,44.0,48.0$ and $55.0 \%$ in midFebruary, first-March, mid-March, first-April, and mid-April, respectively.

Table 1: Fluctuation in the population numbers of $M$. persicae in the $1^{\text {st }}$ plot release at level (30eggs) of C. septempunctata at Behera Governorate.

\begin{tabular}{|l|c|c|c|}
\hline \multicolumn{1}{|c|}{ Date } & Release plot & Chick plot (Control) & \% Reduction \\
\hline First February & 35 & 37 & - \\
\hline Mid February & 30 & 40 & 21.0 \\
\hline First March & 23 & 44 & 31.0 \\
\hline Mid March & 15 & 50 & 41.0 \\
\hline First April & 10 & 59 & 44.0 \\
\hline Mid April & 6 & 70 & 50.0 \\
\hline F (0.05) & \multicolumn{3}{|c|}{} \\
\hline LSD & \multicolumn{3}{|c|}{$\mathbf{1 . 2 2}$} \\
\hline
\end{tabular}




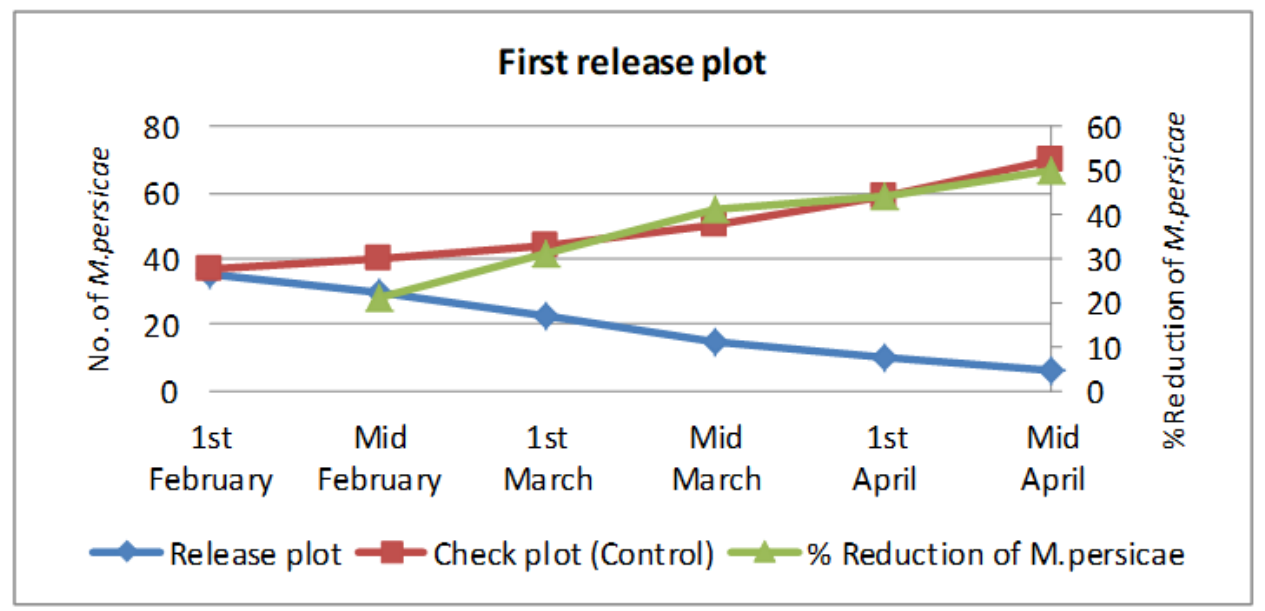

Fig.1: Fluctuation in the population numbers of $M$. persicae in the $1^{\text {st }}$ plot release at level (30eggs) of C. septempunctata at Behera Governorate.

Table 2: Fluctuation in the population numbers of $M$. persicae in the $2^{\text {nd }}$ plot release at level (60eggs) of C. septempunctata at Behera Governorate.

\begin{tabular}{|l|c|c|c|}
\hline \multicolumn{1}{|c|}{ Date } & Release plot & Chick plot (Control) & \% Reduction \\
\hline First February & 33 & 35 & - \\
\hline Mid February & 27 & 39 & 27.0 \\
\hline First March & 21 & 45 & 33.0 \\
\hline Mid March & 14 & 53 & 44.0 \\
\hline First April & 9 & 65 & 48.0 \\
\hline Mid April & 5 & 79 & 55.0 \\
\hline F (0.05) & \multicolumn{3}{|c|}{} \\
\hline LSD & $\mathbf{2 4 5 . 7 5}$ \\
\hline
\end{tabular}

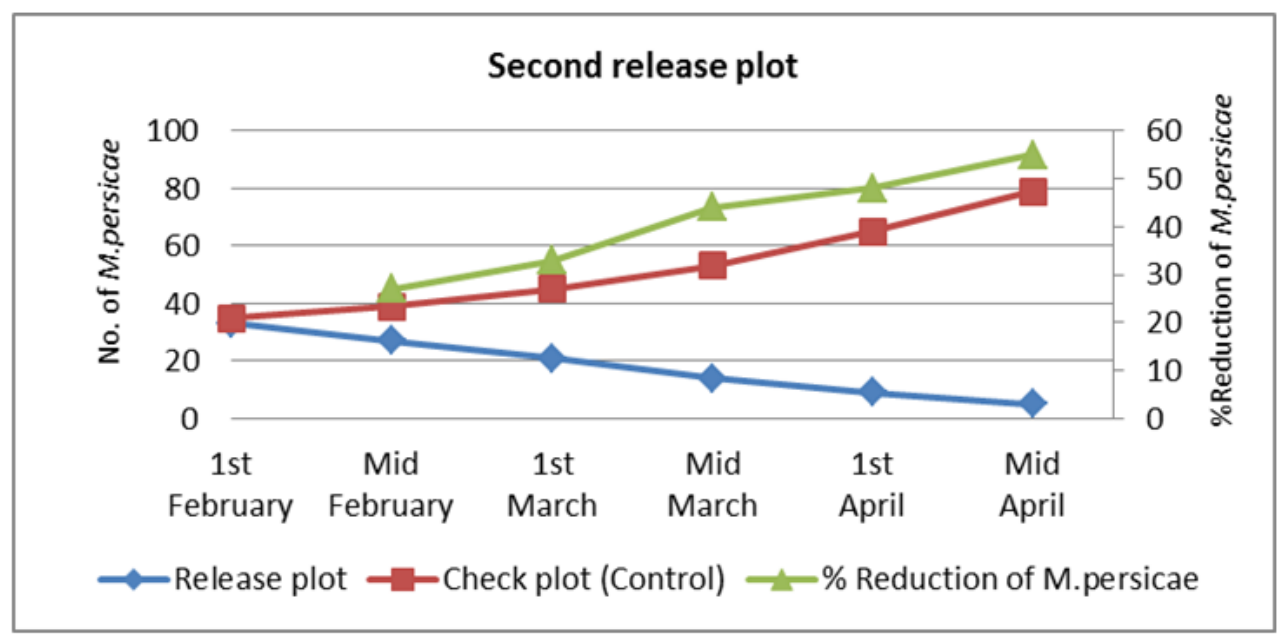

Fig.2: Fluctuation in the population numbers of M. persicae in the $2^{\text {nd }}$ plot release at level (60eggs) of C. septempunctata at Behera Governorate

\section{The Third Level of Release (90 eggs/plant):}

Results in Table (3) and Figure (3) indicated that the number of $M$. persicae in the $3^{\text {rd }}$ release plot decreased gradually from 31 on the $1^{\text {st }}$ February to $27,20,15,9$ and 5 individuals/plant on mid-February, first-March, mid-March, first-April and mid-April, respectively as compared to control which aphid populations changed from 33 
individuals/plant on first-February to 40, 47, 59, 69 and 79 individuals/plant, in the same dates, respectively. The results showed that the percent reduction of $M$. persicae in the $3^{\text {rd }}$ release plot increased gradually to reach 29.0, 37.0, 41.0, 49.0 and 52.0\% in mid-February, first-March, mid-March, first-April and mid-April, respectively.

Table 3: Fluctuation in the population numbers of $M$. persicae in the $3^{\text {rd }}$ plot release at level (90eggs) of C. septempunctata at Behera Governorate.

\begin{tabular}{|l|c|c|c|}
\hline \multicolumn{1}{|c|}{ Date } & Release plot & Chick plot (Control) & \% Reduction \\
\hline First February & 31 & 33 & - \\
\hline Mid February & 27 & 40 & 29.0 \\
\hline First March & 20 & 47 & 37.0 \\
\hline Mid March & 15 & 59 & 41.0 \\
\hline First April & 9 & 69 & 49.0 \\
\hline Mid April & 5 & 79 & 52.0 \\
\hline F (0.05) & \multicolumn{3}{|c|}{} \\
\hline LSD & $\mathbf{2 3 5 . 2 7}$ \\
\hline
\end{tabular}

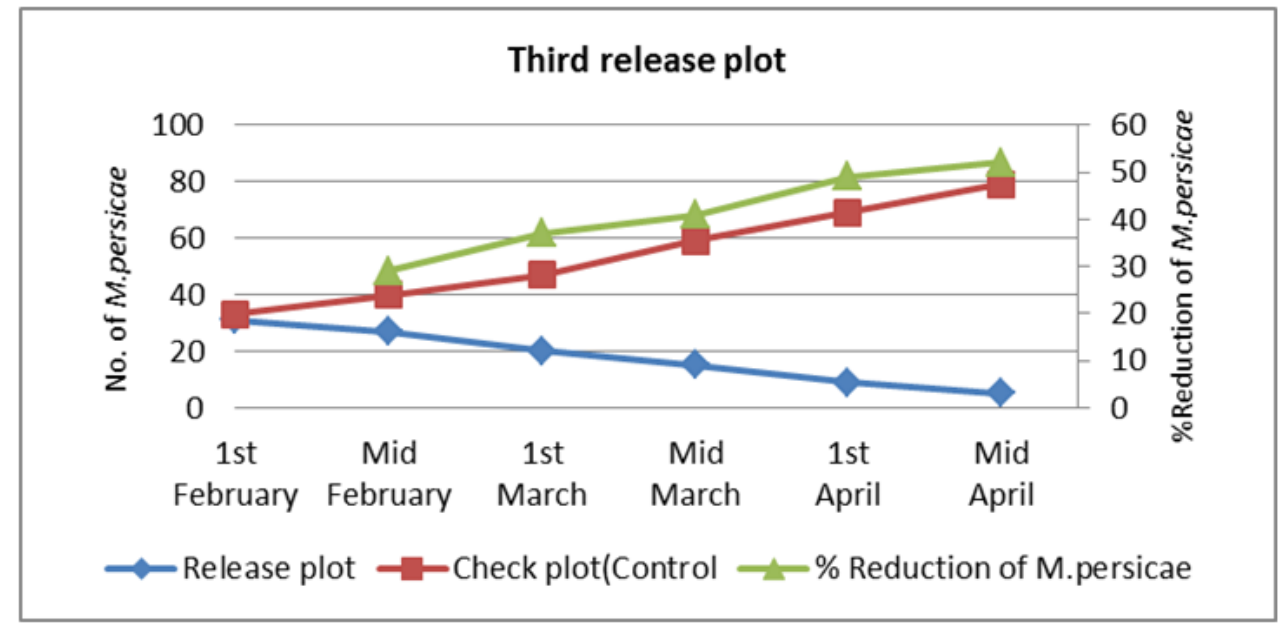

Fig.3: Fluctuation in the population numbers of $M$. persicae in the $3^{\text {rd }}$ plot release at level (90eggs) of C. septempunctata at Behera Governorate.

\section{Perkash (Giza Governorate):}

Also, three levels of $C$. septempunctata eggs; first level (30 eggs on one card), the second level (60 eggs on two cards) and the third level (90 eggs on three cards) were released (one time), by the beginning of February 2020 on strawberry plants.

\section{First Level of Release (30 eggs/plant):}

Results in Table (4) and Figure (4) indicated that the number of $M$. persicae in the $1^{\text {st }}$ release plot decreased gradually from 37 on the $1^{\text {st }}$ February to $32,27,21,13$, and 7 individuals/plant on mid-February, first-March, mid-March, first-April and mid-April, respectively as compared to control which aphid populations changed from 40 individuals/plant on first-February to $44,51,58,67$ and 78 individuals/plant in the same dates, respectively. In addition, the results showed that the percent reduction of $M$. persicae in the $1^{\text {st }}$ release plot increased gradually to reach $22.0,28.0,32.0,47.0$ and $54.0 \%$ in midFebruary, first-March, mid-March, first-April and mid-April, respectively. 
Table 4: Fluctuation in the population numbers of $M$. persicae in the $1^{\text {st }}$ plot release at level (30eggs) of C. septempunctata at Giza Governorate.

\begin{tabular}{|l|c|c|c|}
\hline \multicolumn{1}{|c|}{ Date } & Release plot & Chick plot (Control) & \% Reduction \\
\hline First February & 37 & 40 & - \\
\hline Mid February & 32 & 44 & 22.0 \\
\hline First March & 27 & 51 & 28.0 \\
\hline Mid March & 21 & 58 & 32.0 \\
\hline First April & 13 & 67 & 47.0 \\
\hline Mid April & 7 & 78 & 54.0 \\
\hline F (0.05) & \multicolumn{3}{|c|}{} \\
\hline LSD & \multicolumn{3}{|c|}{$\mathbf{1 . 4 4}$} \\
\hline
\end{tabular}

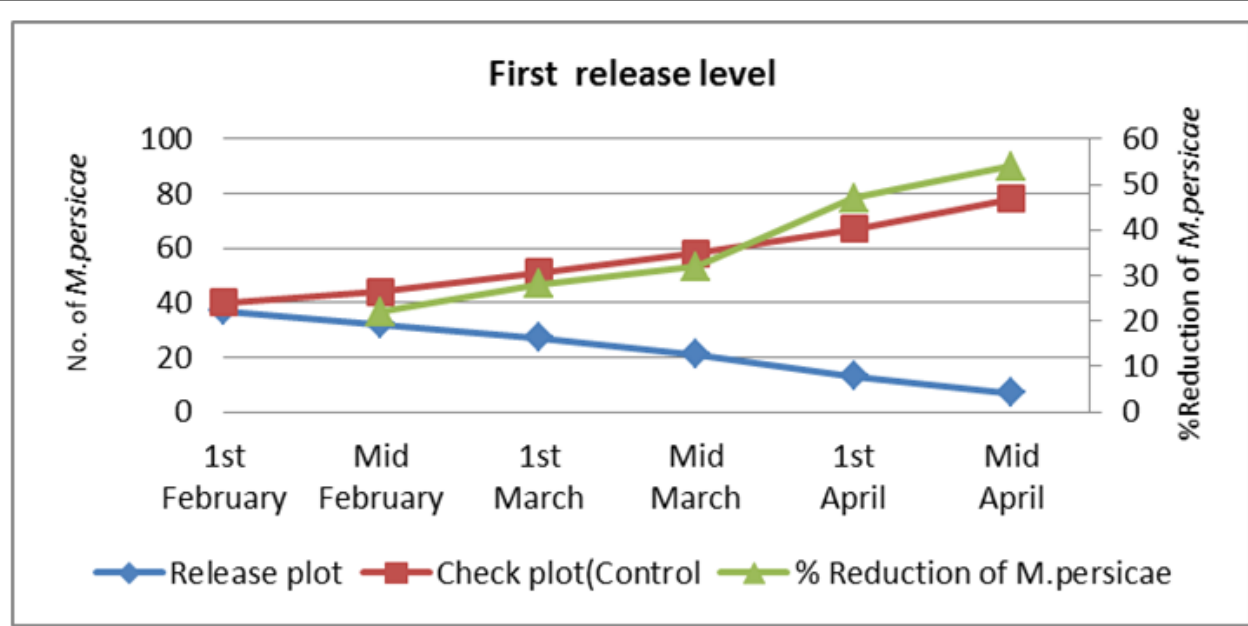

Fig.4: Fluctuation in the population numbers of $M$. persicae in the $1^{\text {st }}$ plot release at level (30eggs) of C. septempunctata at Giza Governorate.

\section{Second Level of Release (60 eggs/plant):}

Results in Table (5) and Figure (5) indicated that the number of M. persicae in the $2^{\text {nd }}$ release plot decreased gradually from 35 on the $1^{\text {st }}$ February to $30,24,17,10$ and 4 individuals/plant in mid-February, first-March, mid-March, first-April and mid-April, respectively as compared to control which aphid populations changed from 37 individuals/plant on first-February to 42, 49, 58, 69 and 77 individuals/plant in the same dates, respectively. In addition, the results showed that the percent reduction of $M$. persicae in the $2^{\text {nd }}$ release plot increased gradually to reach $25.0,32.0,41.0,51.0$ and $65.0 \%$ in midFebruary, first-March, mid-March, first-April and mid-April, respectively.

Table 5: Fluctuation in the population numbers of $M$. persicae in the $2^{\text {nd }}$ plot release at level (60eggs) of C. septempunctata at Giza Governorate

\begin{tabular}{|l|c|c|c|}
\hline \multicolumn{1}{|c|}{ Date } & Release plot & Chick plot (Control) & \% Reduction \\
\hline First February & 35 & 37 & - \\
\hline Mid February & 30 & 42 & 25.0 \\
\hline First March & 24 & 49 & 32.0 \\
\hline Mid March & 17 & 58 & 41.0 \\
\hline First April & 10 & 69 & 51.0 \\
\hline Mid April & 4 & $\mathbf{2 4 1 . 2 8}$ & 65.0 \\
\hline F (0.05) & \multicolumn{3}{|}{} \\
\hline LSD & \multicolumn{3}{|c|}{} \\
\hline
\end{tabular}




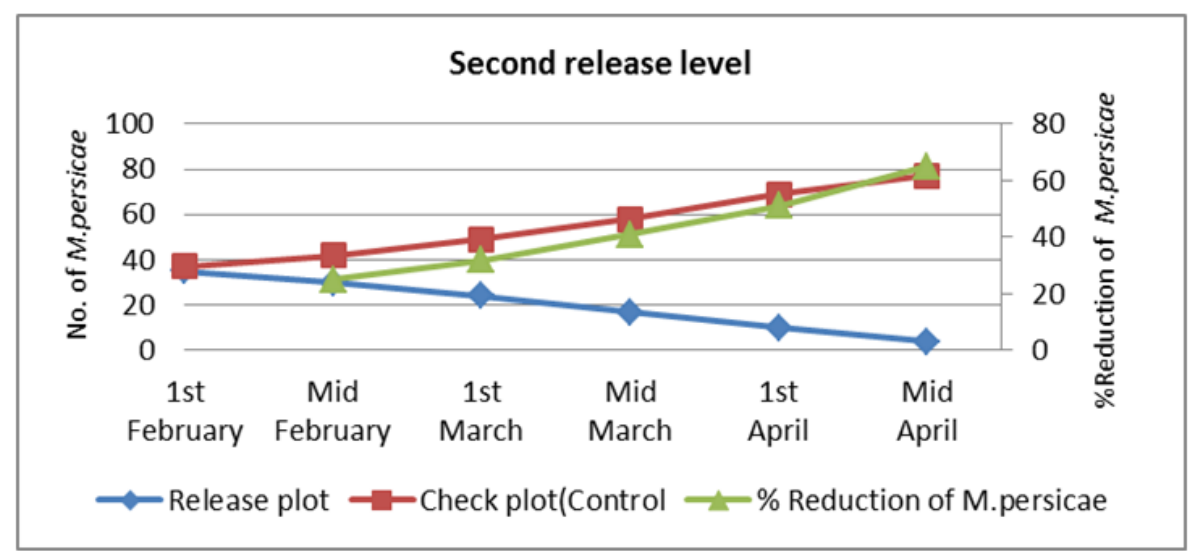

Fig.5: Fluctuation in the population numbers of $M$. persicae in the $2^{\text {nd }}$ plot release at level (60eggs) of C. septempunctata at Giza Governorate.

\section{In Third Level of Release (90 eggs/plant):}

Results in Table (6) and Figure (6) indicated that the number of $M$. persicae in the $3^{\text {rd }}$ release plot decreased gradually from 33 on the $1^{\text {st }}$ February to $29,22,15,8$, and 3 individuals/plant on mid-February, first-March, mid-March, first-April and mid-April, respectively as compared to control which aphid populations changed from 35 individuals/plant on first- February to 40, 49, 58, 67 and 75 individuals/plant on the same dates respectively. In addition, the results showed that the percent reduction of $M$. persicae in the $3^{\text {rd }}$ release plot increased gradually to reach $24.0,39.0,43.0,54.0$ and $67.0 \%$ on midFebruary, first-March, mid-March, first-April and mid-April, respectively.

Table 6: Fluctuation in the population numbers of $M$. persicae in the $3^{\text {rd }}$ plot release at level (90eggs) of C. septempunctata at Giza Governorate.

\begin{tabular}{|l|c|c|c|}
\hline \multicolumn{1}{|c|}{ Date } & Release plot & Chick plot (Control) & \% Reduction \\
\hline First February & 33 & 35 & - \\
\hline Mid February & 29 & 40 & 24.0 \\
\hline First March & 22 & 49 & 39.0 \\
\hline Mid March & 15 & 58 & 43.0 \\
\hline First April & 8 & 67 & 54.0 \\
\hline Mid April & 3 & 75 & 67.0 \\
\hline F (0.05) & \multicolumn{3}{|c|}{} \\
\hline LSD & $\mathbf{2 8 6 . 3 3}$ \\
\hline
\end{tabular}

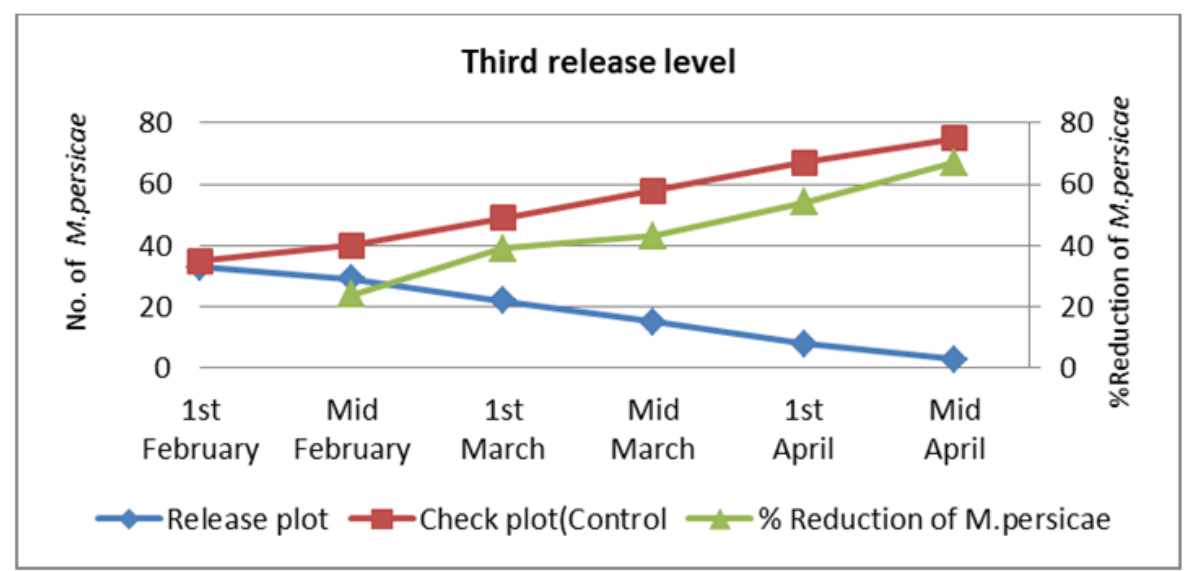

Fig.6: Fluctuation in the population numbers of $M$. persicae in the $3^{\text {rd }}$ plot release at level (90eggs) of C. septempunctata at Giza Governorate. 
Statistical analysis showed that highly significant differences between the three releasing levels (30, 60 and 90 eggs/plant) of $C$. septempunctata predator in the reduction of M. persicae at both the two locations compared to control, whereas (F 0.05) value and (LSD) were $(235.41,1.22),(245.75,1.42)$ and $(235.27,1.32)$, respectively for the three releasing levels (30, 60 and 90 eggs/plant) of C. septempunctata predator at Behera Governorate. Also, at Giza Governorate statistical analysis show highly significant differences between the three releasing levels (30,60 and 90 eggs/plant) of $C$. septempunctata predator in a reduction of $M$. persicae compared to control whereas (F 0.05) value and (LSD) were $(265.27,1.44)$, $(241.28,1.35)$ and $(286.33,1.27)$, respectively for the three releasing levels $(30,60$ and 90 eggs/plant) of $C$. septempunctata predator at Giza Governorate.

These results are in agreement with those obtained by Mangoud (2009) the seven spotted lady beetle, $C$. septempunctata is an important predator of aphids play a good role in reducing the population density of the woolly apple aphid, Eriosoma lanigerum (Hausmann) (Homoptera: Aphididae) attacking apple trees. Also, these results are in agreement with those obtained by Mangoud (2003) who stated that the seven spotted lady beetle, $C$. septempunctata is an important predator of aphids play a good role in reducing the population density of the green peach aphid,

Myzus persicae and the cotton aphid, Aphis gossypii (Hausmann) (Homoptera: Aphididae) attacking apple trees.

Also, these results are in harmony with those obtained by Hoyt and Madsen (1960) found that the control of aphid species complex is complicated by the continued dispersal of aphids from the roots to the aerial portions of the tree, and a corresponding dispersal in the opposite direction. Brar and Kanwar (1994) in field experiments in India found $C$. septempunctata was an effective predator against $A$. craccivora infesting fenugreek germplasm. El-Aish et al. (2004) stated that the role of the predator C. septempunctata in biological suppressing of cereal aphids showed that the eggs last 2-3 days and the 1st, 2nd, 3rd and 4th larval instars have lasted 3, 2, 2 and 4 days, respectively, the pupal stage lasted 8 days at the room temperature. The adult predator consumed 46.13 aphids, while the larval consumed 26.9 aphids daily. Fang et al. (1984) found the coccinellids, C. septempunctata good controlling $B$. brassicae in cotton fields at yellow River valley in China.

\section{REFERENCES}

Anonymous (1997): Ladybird Beetle. Microsoft Encarta 97 Encyclopedia. Houghton Mifflin Company.

Arnett, J.; Ross, N. M. and Jaques, H. E. (1980): How to know the beetles. W. C. Brown Company Publishers, Dubuque, LOWA.

Bilashini, Y.; Singh, T. K. and Singh, R. K. (2017): Biological control potential of Coccinella septempunctata Linnaeus (Coleoptera: Coccinellidae) on major Homopteran pests of rapeseed. Journal of Biological Control, 2 (21): 157-162.

Brar, K. S. and Kanwar, J. S. (1994): Management of Aphis craccivora infesting fenugreek germplasm. Punjab-Vegetable-Grower, 31: 41-44.

El-Aish, H. S., El-Ghariani, I. M. and Al-Mabruk, A. H. (2004): Survey of cereal aphids and their natural enemies and effect of the predator Coccinella septemunctata on biological suppression of cereal aphids in Al-Jabal Al-Akhdar Region, Libya. Proceeding of $1^{\text {st }}$ Arab Conference or Applied Biological Pest Control, Cairo, Egypt, 5-7 April 2004. Egyptian Journal of Biological Pest Control, 14(1): 285290.

Fang, C.; Wen, S.; Cul, S. and Wang, Y. (1984): The role of natural enemies in the integrated control of insect pests on cotton. China cotton, 2: 42-43. 
Fleming, R. C. (2000): Entomology Notes 6: Lady Beetles. http://insects.ummz.1 sa.umich. edu/MES/notes/entnotes6.html

Food and Agriculture Organization (F.A.O) (2017): "FAO Stresses the importance of innovative approaches during meeting of the committee on World Food Security". F. A. O., 6(3): 25-26.

Francisco, A.; Rosario, B. and Jose, L. (2011). The strawberry plant defense mechanism: a molecular review. Plant and cell physiology, 52(11), 1873-1903

Hendrson, C. F. and Tilton, E. W. (1955): Test with acaricides against the brown wheat mite. Journal of Economic Entomology, 48: 157-161.

Hoyt, S. C. and Madsen, H. F. (1960): Dispersal behavior of the first instar nymphs of the woolly apple aphid. Hilgardia, 30: 267-297.

Ibrahim, M. M. (1948): The morphology and anatomy of Coccinella undecimpunctata Reiche. Bulletin de la Société entomologique d'Égypte,XXXII: 305-316

Ibrahim, M. M. (1955): Studies on Coccinella undecimpunctata Reiche Preliminary notes and morphology of the early stages. Bulletin de la Société entomologique d'Égypte,XXXIX: 251-274

Jian, L. and Nick, C. (2009). Current status of the green peach aphid,M. persicae, susceptibility to neonicotinoid and conventional insecticides on strawberries in Southern California. Pest Management Science: formerly pesticide science, 65(3): 645-653

John, B.; Toscano, N. and Ballmer, G. (2005). Greenhouse and field evaluation of six novel insecticides against the green beach aphid, Myzus persicae on strawberries. Crop protection, $11(3)$ : $45-53$

Lundgren, J. G. (2015). Relationships of natural enemies and non-prey foods. Springer International, Dordrecht, The Netherlands.

Mahyoub, J. A.; Mangoud, A. A. H.; AL-Ghamdi, K. M. and Al- Ghramh, H. A. (2013): Mass production the seven spotted lady beetle, Coccinella septempunctata (Coleoptera : Coccinella) and suitable manipulation of picking. Egyptian Academic Journal of Biological Sciences,A. Entomology, 6(3): 31 -38.

Mangoud, A. A. H. (2000): Integrated pest management of apple trees. Ph. D. Thesis, Fac. Agric. Cairo Univ. Cairo, Egypt, 225pp.

Mangoud, A. A. H. (2003): "Mass rearing of parasites and predators attacking mealybugs and whiteflies". Journal of Agricultural Research, 75(1): 235-245.

Mangoud, A. A. H. (2009): Manipulation of the seven spotted lady beetle, Coccinella septempunctata (Coleoptera: Coccinellidae) for controlling the wooly apple aphid, Eriosoma lanigerum (Homoptera: Aphididae). Journal of Agricultural Research, 85(2): 441-451.

SAS Institute 1988. SAS/STAT User`s Guide, Ver. 6.03. SAS Institute Inc., Cary, North Carolina.

Waldbauer, G. (1998): The Birder's Bug Book. Harvard University Press, Cambridge, Massachusetts. 


\section{ARABIC SUMMARY}

المكافحة الحيوية لحشرة من الخوخ الأخضر Myzus persicae علي نباتات الفراولة بإطلاق خنفساء أبو العيد ذو

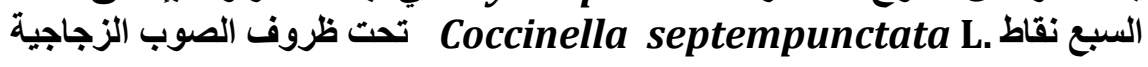

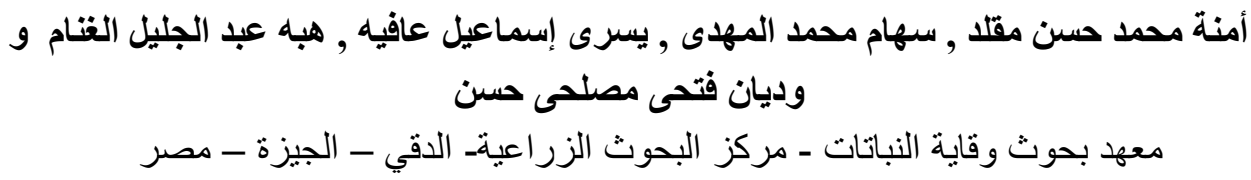

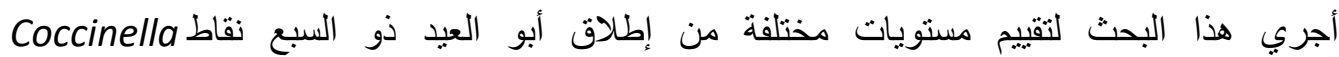
Myzus persicae septempunctata L.

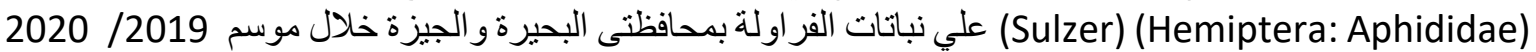

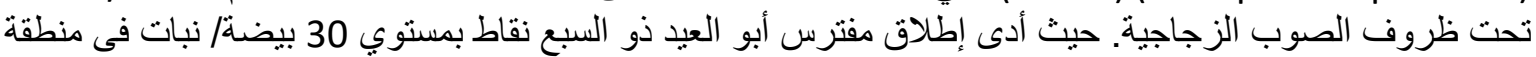

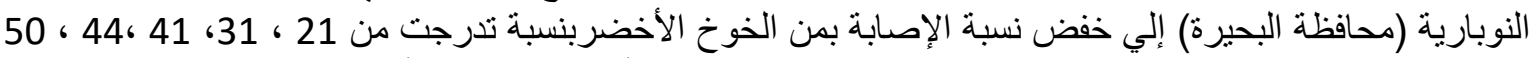

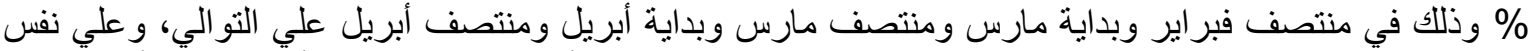

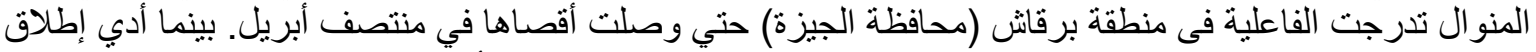

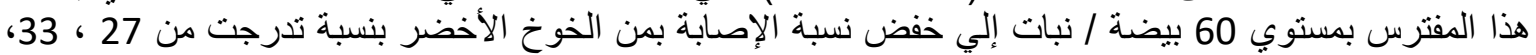

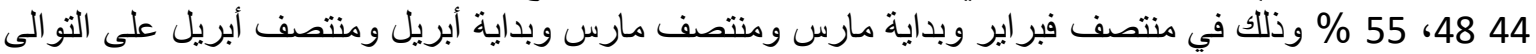

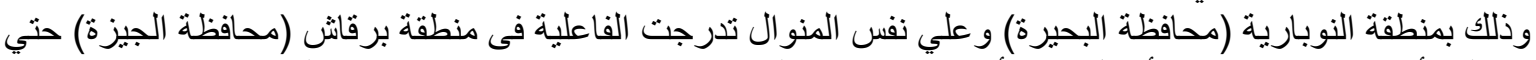

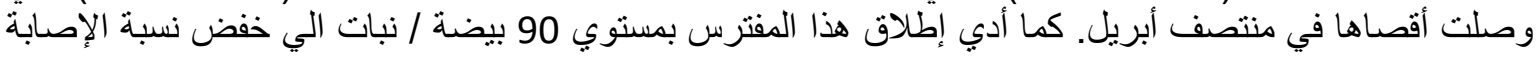

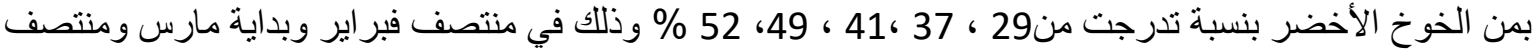

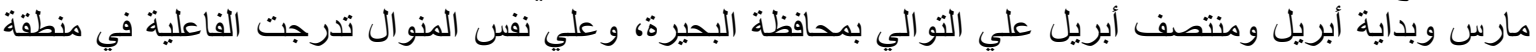

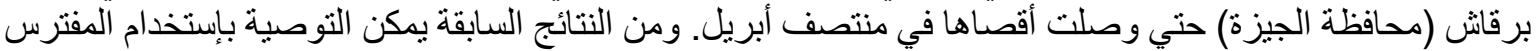

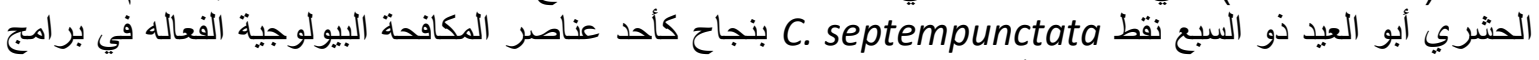
المكافحة المتكاملة لحشرة من الخوخ الأخضر M. persicae علي نباتات الفر اولة. 